\title{
Evaluation of Soil Physical and Chemical Properties under Rice-based Cropping System in Alfisols of Northern Hill Region of Chhattisgarh
}

\author{
R. S. Rajpoot*, R. K. Bajpai, L. K. Shrivastava, Uttam Kumar, \\ K. Tedia and V. N. Mishra \\ Department of Soil Science and Agricultural Chemistry, Indira Gandhi Krishi \\ Vishwavidyalaya, Raipur, Chhattisgarh India \\ *Corresponding author
}

\section{A B S T R A C T}

\begin{tabular}{|c|}
\hline Keywords \\
\hline $\begin{array}{l}\text { Physical properties, } \\
\text { Chemical } \\
\text { properties, Rice- } \\
\text { based cropping } \\
\text { system }\end{array}$ \\
\hline Article Info \\
\hline $\begin{array}{l}\text { Accepted: } \\
18 \text { December } 2020 \\
\text { Available Online: } \\
10 \text { January } 2021\end{array}$ \\
\hline
\end{tabular}

\section{Introduction}

Soil is a basic natural resource which directly benefits the goods and services of various ecosystems for mankind. Its degradation and loss cannot be restored in the human life cycle. Soil is the reference note in order to the production of fuel, food, fibre, and many key ecosystem servicing. Although the production function of soil has long been recognized, the importance of protecting and enhancing the ecosystem services illustrated by soil (such as carbon sequestration, water purification, groundwater recharge, pathogen control, biological nitrogen fixation, and biodiversity conservation) has been valued. The problem of maintaining/improving soil quality appeared long after the maintenance of water 
and soil quality. The soil process makes the soil itself regarded as an ecosystem, rather than an integral part of the ecosystem (Filip 2002 and Nortcliff 2002).

Although many indicators on soil health and soil quality have suggested, there is no globally accepted and applicable definition and method for evaluating soil quality or soil health. In addition, compared with the prediction of the ability of the soil to continue function under a certain range of stress and disturbance, existing knowledge can better understand the current ability of the soil to operate. Another limitation of most existing studies is that efforts have been made to measure the characteristics of topsoil rather than the entire profile (Sparling et al., 2004).

In countries like India, population growth within a limited geographic area is a rapidly growing issue, and crop intensification will accelerate the decline in production. In turn, this has created countless problems in food supply. To meet the growing demand for food, agricultural communities must produce more and more agricultural products. However, in the current situation where land has become a limiting factor, it is impossible to increase the cultivated area to meet the growing demand (Kumar et al., 2019a). The only possibility to solve such problems is to increase production in the vertical direction. To this end, assessment of soil quality is essential to find out the best management practices for sustaining intensive cultivation.

The Soil quality indicators have been wellknown as soil procedures and attributes that are touchy to adjustments in soil work. It must be extremely major to set up a basic, delicate and achievable strategy for assessing soil quality (Aparicio and Costa 2007; Dumanski and Pieri 2000). Soil quality indicators should consolidate physical, chemical, and biological attributes (Karlen et al., 1998; Aparicio and
Costa 2007 and Kumar et al., 2018a, 2019b, 2020). As indicated by reports, when directing SQ examines, the accompanying qualities are reasonable for use as SQ markers: (a) Physical attributes, for example, surface, mass thickness, water maintenance, air penetrability, compressibility, pressure driven qualities, collection state, consistency qualities and surface outside layer; (b) Chemical properties, for example, $\mathrm{pH}$, salt substance, all out natural carbon, dissolvable carbon, mineral nitrogen, complete phosphorus, extractable ammonium, nitrate, phosphorus, potassium, calcium, magnesium, follow components, contaminants and cations ability to change; (c)

Korea District is the part of Chhattisgarh state of India and classified under hot humid eastern plateau of Agro-climatic zone of the country. The average annual rainfall for the district is $1130 \mathrm{~mm}$. Rice based cropping systems are predominantly practiced by the farmers in the district which include chickpea, wheat, linseed, field pea, fallow etc. As the soil and climate of these regions are more favorable for rice cultivation in Kharif, and subsequent crop are chosen by farmers as per soil type, available recourses, and irrigation facilities in Rabi. Farmers cultivate intensive rice based cropping system with improper management practices that involves imbalance and injudicious use of nutrients, low farm input, and removal of residues from field may lead to diminish the SOC of the studied soils. The low level of SOC decline the productivity and sustainability of intensive rice based cropping system. The decline in SOC ultimately deteriorates the soil quality in long run as SOC is the key contributor of soil quality. However, we hypothesized that inclusion of legumes into in rice-based cropping system improves the soil quality. Many workers have studied that improvement in soil quality due to incorporation of legumes either as green manures or as residues. 
However the detailed information regarding impacts of different rice-based cropping systems, including rice-legume, on soil quality in particular is not available especially for soils of hot humid eastern plateau of India. Keeping all these points into account, the present study entitled Soil Physical and Chemical Quality under Rice-based Cropping System in Alfisols of Northern Hill Region of Chhattisgarh have been carried out for suggesting sustainable succeeding crop with rice.

\section{Materials and Methods}

\section{Research area description}

Korea district is situated at $23.38^{\circ} \mathrm{N}$ latitude and $82.38^{\circ}$ E longitude with elevation $317 \mathrm{~m}$ above the mean sea level, comes under Northern hills agro-climatic zone of Chhattisgarh. The Korea district covers an area of 244800 hectare, broadly divided into 2 major river basins; Ganga basin and Mahanadi basin. The Ganga basin covers $60 \%$ of the area however the remaining area is drained by the Mahanadi basin. physiographically, the district is a part of Northern Hills and characterized by undulating topography with high hills, dissected plateaus, steep slopes and scarps. The Basaltic terrain is characterized by highly undulating topography with steep hills and plateau tops. The district having 54\% area under Kharif (133015 ha) and 29\% in Rabi $(7100 \mathrm{ha})$ cultivation out of the total geographical area. Major soil types of study area are Entisols (Dand-gravely), Inceptisols (Chawar-sandy loam), Alfisols (Gadar Chawar - clay loam) and Vertisols (Bahera - clayey). Stratified-random soil sampling was done from the $10 \%$ of the total villages in the" district. In each village, "based on the cropping" system, soil "samples were taken from"Alfisols. Composite "surface $(0-15 \mathrm{~cm})$ soil samples were collected from each site after the harvest of cropping" system, where the crop rotation was followed since 2010. From each site, five soil samples were collected and pooled as composite sample (0$15 \mathrm{~cm}$ depth) after the harvest of cropping system. The average yield of the crop taken for ten year period (2010- 2019) was recorded by farmer's interactions.

\section{Sampling and survey}

The Korea district is having five Blocks (Tehsils) namely Baikunthpur, Sonhat, Bharatpur, Manendragad and Khadgaon. There are a total of 373 Village Panchayats in the district. A total of 120 samples were collected from six most prominent cropping systems for study. A soil survey of Korea district was carried out and identified one important soil order i.e. Alfisols (Gadar Chawar - clay loam). This restriction is imposed in order to closely access the effects of land use on soil quality without the confounding effects of sampling multiple soil orders. Under Alfisol order, the following most prominent cropping sequences were identified for further detailed study: 1.Rice Mustard (RM) 2.Rice - Wheat (RW) 3.Rice Linseed (RL) 4. Rice - Chickpea (RC) 5.Rice-field pea (RF) 6.Rice-Fallow (RF)

\section{Laboratory analysis}

Among the physical properties, particle-size distribution was measured by International Pipette method (Jackson 1973), bulk density (BD), and particle density (PD) was estimated as per the method no. 39, USDA Hand book no. 60 (Richards 1954). Soil porosity was calculated using the data of BD and PD. The water holding capacity (WHC) was measured by Keen raczkowski box method described by Kumar et al., (2018b), SMC determined by Gravimetric method as prescribed by Kumar et al., (2018b) and aggregate size distribution by Yodar modified wet sieving method as 
described by Yoder (1936) as mean weight diameter (MWD).

Soil $\mathrm{pH}$ and electrical conductivity (EC) were measured with 1: 2.5 soil: water ratio as per method described by Richards (1954); organic carbon (OC) was determined by Walkley Black's wet digestion method (Walkley and Black 1934). The available $\mathrm{N}$ was determined by using alkaline potassium permanganate $\left(\mathrm{KMnO}_{4}\right)$ solution by determining the ammonia liberated (Subbiah and Asija 1956). The available $\mathrm{P}$ was determined by Olsen method by using $0.5 \mathrm{M} \mathrm{NaHCO} 3$ extractant (Olsen et al., 1954). The available $\mathrm{K}$ was determined by using neutral ammonium acetate method by using flame photometer (Jackson 1973). Soil available S was measured by turbidimetic method as described by Kumar et al., (2018b). Available micronutrient cations ( $\mathrm{Fe}, \mathrm{Mn}, \mathrm{Cu}$, and $\mathrm{Zn}$ ) were extracted by DTPA-CaCl $\mathrm{C}_{2}$ extractant at pH 7.3 (Lindsay and Norvell 1978) and were measured by using Atomic Absorption Spectrophotometer (AAS). Available B was estimated by hot water method (Berger and Troug 1939).

\section{Statistical analysis}

The statistical analysis of the data was administered using SPSS Statistics (version 25.0, IBM, Armonk, NY, USA).

\section{Results and Discussion}

\section{Soil physical quality}

\section{Bulk density}

Bulk density (BD) is one of the important physical aspects of soils that determine the porosity, aggregate stability and water holding capacity and root development of soils. The bulk density of soils varied from 1.35 to 1.48 (mean 1.43 ) $\mathrm{Mg} \mathrm{m}^{-3}$, from 1.30 to
1.41 (mean 1.33 ) $\mathrm{Mg} \mathrm{m}^{-3}$, from 1.35 to 1.49 (mean 1.40) $\mathrm{Mg} \mathrm{m}^{-3}$, from 1.30 to 1.42 (mean $1.35) \mathrm{Mg} \mathrm{m}^{-3}$, from 1.32 to 1.42 (mean 1.37 ) and from 1.36 to 1.49 (mean 1.44) $\mathrm{Mg} \mathrm{m}^{-3}$ for RW, RC, RM, RP, RL, and RF cropping system, respectively (Table 1). The higher amount of added biomass from leguminous crops made soil loose, porous and less squeezed therefore, the lower bulk density was found under rice-legume cropping system (RC and RP)) (Husnjak et al., 2002; Rahman et al., 2007; Kumar et al., 2018a, 2019b, 2020).

\section{Particle density}

Particle density is the mass of soil solid per unit volume without pore spaces (Hillel 1980) and is important parameter to understand soil physical environment including bulk density and porosity. The particle density of soils was varied from 2.60 to 2.69 (mean 2.63) $\mathrm{Mg} \mathrm{m}^{-}$ ${ }^{3}$ from 2.58 to 2.71 (mean 2.63 ) $\mathrm{Mg} \mathrm{m}^{-3}$, from 2.60 to 2.71 (mean 2.64) $\mathrm{Mg} \mathrm{m}^{-3}$, from 2.54 to 2.68 (mean 2.60) $\mathrm{Mg} \mathrm{m}^{-3}$, from 2.58 to 2.68 (mean 2.62) $\mathrm{Mg} \mathrm{m}^{-3}$ and from 2.61 to 2.70 (mean 2.64) $\mathrm{Mg} \mathrm{m}^{-3}$ for $\mathrm{RW}, \mathrm{RC}, \mathrm{RM}, \mathrm{RP}$, $\mathrm{RL}$, and RF cropping system, respectively (Table 1). Among the cropping systems, the particle density was found to be varying insignificantly (Table 1).

\section{Porosity}

Soil porosity is the best indicator of soil structural quality. Quantification of the pore space in terms of shape, size, continuity, orientation and arrangement of pores in soil allows us to define the complexity of soil structure and to understand its modifications induced by management practices. The porosity of soils was varied from 43.46 to 48.28 (mean 45.74) per cent, from 47.13 to 50.00 (mean 49.13) per cent, from 43.84 to 48.83 (mean 46.77) per cent, from 44.96 to 50.00 (mean 47.92) per cent, from 46.34 to 
49.77 (mean 47.71) and from 43.24 to 48.04 (mean 45.40) for RW, RC, RM, RP, RL, and $\mathrm{RF}$, respectively (Table 1 ). The porosity of soils under RC cropping system was higher than that of soils under RM, RP, RL, and RF cropping systems. Legume based cropping systems is having high carbon sequestration capacity that make soil become more porous and loose than that of other cropping systems (Kumar et al., 2018a, 2019b, 2020)

\section{Water holding capacity (WHC)}

Soil water holding capacity (WHC) is the amount of water that, a given soil can hold for crop use. Field capacity is the point where the soil water holding capacity has reached its maximum for the entire field. The key is for farmers to understand the nuances of soil water holding capacity and how to manage it, so that the farm does not need to irrigate or suffer from a drought. Soil texture and organic matter are the key components that determine water holding capacity of soils. The WHC of soils was varied from 27.83 to 32.98 (mean 30.02) per cent, from 36.23 to 48.32 (mean 41.36) per cent, from 28.65 to 32.20 (mean 30.10) per cent, from 34.65 to 39.80 (mean 36.84) per cent, from 32.68 to 36.23 (mean 34.12) per cent and from 22.64 to 26.19 (mean 24.08) per cent for RW, RC, $\mathrm{RM}$, RP, RL, and RF cropping system, respectively (Table 1). The WHC of soils under RC cropping system was higher than that of soils under RM, RP, RL, and RF cropping systems. Further, WHC of soils under RP cropping system was higher than that of soils under RL and RF cropping systems. In this consequence the WHC of soils under RL cropping system was higher than that of soils under RF cropping systems. Rice-legume cropping system (RC) store large extant of carbon in to the soil. Which bind soil particles, increase mean weight diameter, improve water stable aggregates, and consequently increase in water holding capacity of soil (Schjonning et al., 2002) and Bama and Somasundaram 2017).

\section{Soil moisture content}

Availability of soil moisture is one of the most limiting factors for getting sustainable crop production. However, under changing scenario of climate the available water content is decline continuously. Therefore, it is necessary to adopt the cropping systems that can use list amount of water and maintain soil moisture for longer period of time. The soil moisture content of soils was varied from 21.70 to 23.90 (mean 22.71) per cent, from 25.16 to 38.38 (mean 31.33 ) per cent, from 26.03 to 28.23 (mean 27.03) per cent, from 21.78 to 23.98 (mean 22.79) per cent, from 24.01 to 26.21 (mean 25.01) per cent and from 20.01 to 22.21 (mean 21.02) per cent for $\mathrm{RW}, \mathrm{RC}, \mathrm{RP}, \mathrm{RM}, \mathrm{RL}$, and RF cropping system, respectively (Table 1). The soil moisture content of soils under RC cropping system was higher than that of soils under RM, RP, RL, and RF cropping systems. Ricelegume cropping system (RC and RL) added large amount of biomass in to the soil, which make surface soil loose and porous, improve the aggregation, thus enhance the capacity of soil to store and retain more moisture. Therefore the SMC of rice-legume cropping system (RC and RL) was higher than other cropping system of RW and RF. (Rahman et al., 2007 and Alam and Salahin 2013 and Kumar et al., 2018a, 2019b, 2020).

\section{Mean Weight diameter (MWD)}

The mean weight diameter is commonly used to express aggregate stability as it determines the size distribution of aggregates and is essentially a measure of macro-aggregate stability, as the aggregates that remained on each sieve must be stable to the wetting and sieving processes (Amezketa 1999). The mean weight diameters of soils was varied 
from 0.66 to 0.71 (mean 0.68 ) $\mathrm{mm}$, from 0.77 to 0.91 (mean 0.80 ) $\mathrm{mm}$, from 0.73 to 0.78 (mean 0.75 ) $\mathrm{mm}$, from 0.67 to 0.72 (mean 0.69 ) $\mathrm{mm}$, from 0.69 to 0.74 (mean 0.71 ) $\mathrm{mm}$ and from 0.60 to 0.65 (mean 0.62 ) $\mathrm{mm}$ for RW, RC, RP, RM, RL and RF, respectively (Table 1). The MWD of soils under RC cropping system was higher than that of soils under RM, RP, RL, and RF cropping systems. Further, the MWD of soils under RP cropping system was higher than that of soils under RL and RF cropping systems. In this consequence the MWD of soils under RL cropping system was higher than that of soils under RF cropping systems. Rice-legume cropping system (RC and RL) having high root mass density, mean root diameter, root diameter diversity and the percentage of fine roots was all positively linked to the stability of soil aggregates by increasing soil organic carbon content. Higher root biomass of leguminous crops helped to accumulation of higher amount of soil organic carbon through roots and leaf-fall with increased macro-aggregate formation (Kumar et al., 2018a, 2019b, 2020)

\section{Soil chemical quality}

\section{Soil reaction $(\mathrm{pH})$}

Soil reaction is an indication of acidity, neutrality or salinity/alkalinity of the soil. It is measured and expressed in $\mathrm{pH}$ units. Soil $\mathrm{pH}$ is defined as the negative logarithm of the hydrogen ion activity. Soil $\mathrm{pH}$ affects the soil's physical, chemical, and biological properties and processes, as well as plant growth. The nutrition, growth, and yields of most crops decrease where $\mathrm{pH}$ is low and increase as $\mathrm{pH}$ rises to an optimum level (6.5 to 7.5). The $\mathrm{pH}$ of soil was varied from 6.32 to 7.18 (mean 6.88), from 5.71 to 7.89 (mean 6.28 ), from 5.91 to 8.40 (mean 6.86), from 6.04 to 7.49 (mean 6.54), from 6.00 to 8.13 (mean 6.73), and from 5.63 to 8.12 (mean 7.04) for RW, RC, RM, RP, RL and RF, respectively (Table 1 ). The $\mathrm{pH}$ of soils under RC cropping system was lower than that of soils under RM and RF cropping systems. For other cropping systems the differences in organic carbon were found to be insignificant. Leguminous crop fix atmospheric $\mathrm{N}$ in crop root zone with the help of rhizobium bacteria. Nitrogen is acid forming nutrient that reduce the soil $\mathrm{pH}$ under legume- based cropping systems.

\section{Electrical conductivity (EC)}

Soil EC is a measure of the amount of salts in soil (salinity of soil). It is an important indicator of soil quality. It affects crop yields, crop suitability, plant nutrient availability, and activity of soil microorganisms which influence key soil processes including the emission of greenhouse gases such as nitrogen oxides, methane, and carbon dioxide. Excess salts hinder plant growth by affecting the soil-water balance. The EC of soils was varied from 0.04 to 0.24 (mean 0.14 ) $\mathrm{dS} \mathrm{m}^{-1}$, from 0.11 to 0.24 (mean 0.15 ) $\mathrm{dS} \mathrm{m}^{-1}$, from 0.12 to 0.24 (mean 0.16 ) $\mathrm{dS} \mathrm{m}^{-1}$, from 0.04 to 0.20 (mean 0.16 ) $\mathrm{dS} \mathrm{m}^{-1}$, from 0.14 to 0.22 (mean 0.17) $\mathrm{dS} \mathrm{m}^{-1}$ and from 0.07 to 0.24 (mean 0.14) $\mathrm{dS} \mathrm{m}^{-1}$ for RW, RC, RP, RM, $\mathrm{RL}$, and RF cropping system, respectively (Table 1). The studied soils are acidic in nature, while the EC of soils characterize the soil salinity. Therefore, among the cropping systems EC of soils was differing insignificant.

\section{Organic carbon (OC)}

Soil carbon is probably the most important component in soils as it affects the soil properties. Carbon as soil organic matter influences the physical, chemical, and biological properties of the soils. Soil organic carbon is often considered as the largest contributor to soil quality (Shukla et al., 2006 and Abid and Lal 2008). Improvements in soil 
organic matter create a more favourable environment, leading to increases in crop productivity. The organic carbon of soils was varied from 3.89 to 4.96 (mean 4.20 ) $\mathrm{g} \mathrm{kg}^{-1}$, from 6.03 to 7.11 (mean 6.35 ) $\mathrm{g} \mathrm{kg}^{-1}$, from 5.18 to 6.34 (mean 5.62 ) $\mathrm{g} \mathrm{kg}^{-1}$, from 4.10 to 5.17 (mean 4.41 ) $\mathrm{g} \mathrm{kg}^{-1}$, from 4.71 to 6.42 (mean 5.04) $\mathrm{g} \mathrm{kg}^{-1}$ and from 3.70 to 4.77 (mean 4.14) $\mathrm{g} \mathrm{kg}^{-1}$ for RW, RC, RP, RM, RL and RF cropping system, respectively (Table 1). The organic carbon of soils under RC cropping system was higher than that of soils under RM, RP, RL, and RF cropping systems. Further, the organic carbon of soils under RP cropping system was higher than that of soils under RL and RF cropping systems. Higher soil organic carbon was observed in the ricelegume cropping system (RC and RL) may be attributed to these rotations was considered to have high root biomass, higher carbon sequestration capacity and less carbon release than that of soils under RW and RF cropping system (Orchard and Cook 1983 and Mitsch et al., 2010). Similarly, the lower amounts of biomass production in the continuous wheat system in our study ledto lower recovery rates of organic carbon. Moreover, the increment in organic carbons in rice-legume cropping systems (RC and RL) might also have contributed to the increase in soil porosity (Bhattacharyya et al., 2006), soil aggregate stability (Pagliai et al., 2004), plant available water content (Mc Garry et al., 2000), and reduced susceptibility to soil compaction.

\section{Available N}

Nitrogen $(\mathrm{N})$ is a vitally important plant nutrient. Plants contain $1-5 \% \mathrm{~N}$ by weight. It is an essential constituent of proteins having physiological importance in plant metabolism. In soil, $\mathrm{N}$ that is present in organic form appears to be unavailable to plants. The available $\mathrm{N}$ in soil is that portion which is present in mineral forms usually in the form of ammonium and nitrate in the soil solution.
The available $\mathrm{N}$ of soils was varied from 186.66 to 238.05 (mean 207.53) $\mathrm{kg} \mathrm{ha}^{-1}$, from 280.61 to 321.34 (mean 293.65 ) $\mathrm{kg} \mathrm{ha}^{-1}$, from 241.09 to 297.98 (mean 262.68) $\mathrm{kg} \mathrm{ha}^{-1}$, from 196.67 to 248.07 (mean 211.81 ) $\mathrm{kg} \mathrm{ha}^{-1}$, from 218.89 to 298.53 (mean 235.21) $\mathrm{kg} \mathrm{ha}^{-1}$, and from 181.17 to 233.64 (mean 203.23 ) $\mathrm{kg}^{-}$ ${ }^{1}$ for $\mathrm{RW}, \mathrm{RC}, \mathrm{RP}, \mathrm{RM}, \mathrm{RL}$ and RF, respectively (Table 1)

The available $\mathrm{N}$ of soils under $\mathrm{RC}$ cropping system was higher than that of soils under RM, RP, RL, and RF cropping systems. Further, the available $\mathrm{N}$ of soils under RP cropping system was higher than that of soils under RL and RF cropping systems. Legume is a natural mini-nitrogen manufacturing factory in the field (Ghosh et al., 2017) and the farmers by growing these crops can play a vital role in increasing indigenous $\mathrm{N}$ production. Legumes playing a pivotal role especially in N supply to the cereals. Through their symbiotic associations with rhizobium (bacteria in their root nodules), legumes have the ability to fix atmospheric $\mathrm{N}$ into forms that can be utilized by plants. As a result, ricelegume cropping system (RC and RL) store more $\mathrm{N}$ rather than RW and RF (Ghosh et al., 2017; Das and Ghosh 2012; Patrick et al., 2013; Kumar et al., 2018a, 2019b, 2020).

\section{Available P}

Phosphorus (P) is an essential element classified as a macronutrient because of the relatively large amounts required by plants. It is involved in several key plant functions, including energy transfer, photosynthesis, transformation of sugars and starches, nutrient movement within the plants. The available $\mathrm{P}$ of soils was varied from 9.00 to 16.45 (mean 12.85) $\mathrm{kg} \mathrm{ha}^{-1}$, from 13.50 to 24.54 (mean 19.81) $\mathrm{kg} \mathrm{ha}^{-1}$, from 14.53 to 19.10 (mean 17.19 ) $\mathrm{kg} \mathrm{ha}^{-1}$, from 9.54 to 16.15 (mean 13.66) $\mathrm{kg} \mathrm{ha}^{-1}$, from 13.53 to 20.00 (mean 15.88) $\mathrm{kg} \mathrm{ha}^{-1}$ and from 7.30 to 14.23 (mean 
11.22) $\mathrm{kg} \mathrm{ha}^{-1}$ for RW, RC, RP, RM, RL, and $\mathrm{RF}$, respectively (Table 1 ).

The available $\mathrm{P}$ of soils under RC cropping system was higher than that of soils under RM, RP, RL, and RF cropping systems. Further, the available $\mathrm{P}$ of soils under RP cropping system was higher than that of soils under RF cropping systems. A greater $\mathrm{P}$ availability was observed under RC cropping system presumably due to the lower $\mathrm{pH}$, which is discussed earlier. Crop rotations, especially those with legumes, can increase root colonization by mycorrhizae. Mycorrhizal associations have the greatest impact on increasing $\mathrm{P}$ availability for crops by colonizing root. These results are in line with the findings of Newton et al., (2011) and Smith et al., (2011). P supply is enhanced in legume based cropping system through a range of mechanisms which include development of mycorrhizal symbiosis, formation of cluster roots, alteration in root architecture, production of root exudates, as well as induction of phosphatase enzyme activity (Maseko and Dakora 2013; Kumar et al., 2018a, 2019b, 2020).

\section{Available K}

The total $\mathrm{K}$ content of soils frequently exceeds $20,000 \mathrm{ppm}$. Nearly all of this $\mathrm{K}$ is in the structural component of soil minerals and is not available for plant growth. Because of large differences in soil parent materials and the effect of weathering of these materials, only a little amount of soil $\mathrm{K}$ available to plant as soil solution and exchangeable form. The available $\mathrm{K}$ of soils was varied from 282.77 to 428.38 (mean 341.56 ) $\mathrm{kg} \mathrm{ha}^{-1}$, from 316.25 to 549.70 (mean 434.22 ) $\mathrm{kg} \mathrm{ha}^{-1}$, from 296.94 to 442.55 (mean 355.73 ) $\mathrm{kg} \mathrm{ha}^{-1}$, from 346.39 to 448.80 (mean 401.11 ) $\mathrm{kg} \mathrm{ha}^{-1}$, from 336.70 to 471.25 (mean 390.37 ) $\mathrm{kg} \mathrm{ha}^{-1}$ and from 269.88 to 415.49 (mean 328.67 ) $\mathrm{kg} \mathrm{ha}^{-1}$ for RW, RC, RFP, RM, RL and RF cropping system, respectively (Table 1). The available $\mathrm{K}$ of soils under RC cropping system was higher than that of soils under RM, RP, RL and RF cropping systems. Further, the available $\mathrm{K}$ of soils under RP cropping system was higher than that of soils under RF cropping systems. In this consequence the available $\mathrm{K}$ of soils under $\mathrm{RL}$ cropping system was higher than that of soils under RF cropping systems.

\section{Available S}

Sulphur (S) is an essential secondary nutrient, is required by plants in approximately the same amount as $\mathrm{P}$. Approximately 95 percent of the total amount of $S$ in soils is found in the organic matter. As the soil organic matter is decomposed the organic forms of the $\mathrm{S}$ is mineralized to sulfate-sulfur. This $\mathrm{SO}_{4}{ }^{2-} \mathrm{S}$ is the only form of $S$ that is absorbed by plant roots. The available $\mathrm{S}$ of soils was varied from 7.48 to 15.87 (mean 11.78) $\mathrm{kg} \mathrm{ha}^{-1}$, from 12.15 to 21.14 (mean 16.61) $\mathrm{kg} \mathrm{ha}^{-1}$, from 10.03 to 19.02 (mean 14.48 ) $\mathrm{kg} \mathrm{ha}^{-1}$, from 15.85 to 21.91 (mean 19.09 ) $\mathrm{kg} \mathrm{ha}^{-1}$, from 8.45 to 18.90 (mean 14.14 ) $\mathrm{kg} \mathrm{ha}^{-1}$ and from 5.93 to 14.32 (mean 10.24) $\mathrm{kg} \mathrm{ha}^{-1}$ for $\mathrm{RW}$, RC, RP, RM, RL and RF, respectively (Table 1). The available $S$ of soils under $R C$ cropping system was lower than that of soils under RM cropping systems. The available $\mathrm{S}$ of soils under RC cropping system was higher than that of soils under RL and RF cropping systems. Further, the available $\mathrm{S}$ of soils under RP cropping system was higher than that of soils under RF cropping systems. In this consequence the available $\mathrm{S}$ of soils under RL cropping system was higher than that of soils under RF cropping systems. These differences were insignificant for other cropping systems. The Legume based cropping systems retain more amount of $\mathrm{C}$ in to the soil and by the mineralization of this $\mathrm{C}$, sulphur content of the soil enhanced. (Kumar et al., 2018a, 2019b, 2020). 
Table.1 Descriptive statistics of soil properties based on cropping system

\begin{tabular}{|c|c|c|c|c|c|c|c|c|c|c|c|c|c|c|c|c|c|c|}
\hline \multirow[t]{2}{*}{ Soil Property } & \multicolumn{3}{|c|}{ Rice-Wheat } & \multicolumn{3}{|c|}{ Rice-Chickpea } & \multicolumn{3}{|c|}{ Rice-Field pea } & \multicolumn{3}{|c|}{ Rice-Mustard } & \multicolumn{3}{|c|}{ Rice-Linseed } & \multicolumn{3}{|c|}{ Rice-Fallow } \\
\hline & Mean & Min. & Max. & Mean & Min. & Max. & Mean & Min. & Max. & Mean & Min. & Max. & Mean & Min. & Max. & Mean & Min. & Max. \\
\hline BD $\left(\mathrm{Mg} \mathrm{m}^{-3}\right)$ & 1.43 & 1.35 & 1.48 & 1.33 & 1.30 & 1.41 & 1.35 & 1.30 & 1.42 & 1.40 & 1.35 & 1.49 & 1.37 & 1.32 & 1.42 & 1.44 & 1.36 & 1.49 \\
\hline PD $\left(\mathrm{Mg} \mathrm{m}^{-3}\right)$ & 2.63 & 2.60 & 2.69 & 2.63 & 2.58 & 2.71 & 2.60 & 2.54 & 2.68 & 2.64 & 2.60 & 2.71 & 2.62 & 2.58 & 2.68 & 2.64 & 2.61 & 2.70 \\
\hline Porosity (\%) & 45.74 & 43.46 & 48.28 & 49.13 & 47.13 & 50.00 & 47.92 & 44.96 & 50.00 & 46.77 & 43.84 & 48.83 & 47.71 & 46.34 & 49.77 & 45.40 & 43.24 & 48.04 \\
\hline AWHC (\%) & 30.02 & 27.83 & 32.98 & 41.36 & 36.23 & 48.32 & 36.84 & 34.65 & 39.80 & 30.10 & 28.65 & 32.20 & 34.12 & 32.68 & 36.23 & 24.08 & 22.64 & 26.19 \\
\hline SMC (\%) & 22.71 & 22.57 & 23.90 & 31.34 & 31.20 & 38.38 & 27.04 & 26.03 & 28.23 & 22.79 & 21.78 & 23.98 & 25.02 & 24.01 & 26.21 & 21.02 & 20.01 & 22.21 \\
\hline MWD (mm) & 0.69 & 0.67 & 0.71 & 0.81 & 0.78 & 0.91 & 0.76 & 0.73 & 0.78 & 0.70 & 0.67 & 0.72 & 0.72 & 0.69 & 0.74 & 0.63 & 0.60 & 0.65 \\
\hline pH & 6.88 & 6.32 & 7.18 & 6.28 & 5.71 & 7.89 & 6.54 & 6.04 & 7.49 & 6.86 & 5.91 & 8.10 & 6.73 & 6.00 & 8.13 & 7.04 & 5.63 & 8.12 \\
\hline $\mathrm{EC}\left(\mathrm{dS} \mathrm{m^{-1 } )}\right.$ & 0.15 & 0.04 & 0.24 & 0.15 & 0.11 & 0.24 & 0.17 & 0.12 & 0.24 & 0.16 & 0.04 & 0.20 & 0.18 & 0.14 & 0.22 & 0.14 & 0.07 & 0.24 \\
\hline OC (g kg-1) & 4.20 & 3.89 & 4.96 & 6.35 & 6.03 & 7.11 & 5.62 & 5.18 & 6.34 & 4.41 & 4.10 & 5.17 & 5.04 & 4.71 & 6.42 & 4.15 & 3.70 & 4.77 \\
\hline $\begin{array}{l}\text { Av. N (kg ha- } \\
\left.{ }^{-}\right)\end{array}$ & 207.54 & 186.66 & 238.05 & 293.66 & 280.61 & 321.34 & 262.69 & 241.09 & 297.98 & 211.81 & 196.67 & 248.07 & 235.21 & 218.89 & 298.53 & 203.23 & 181.17 & 233.64 \\
\hline $\begin{array}{l}\text { Av. P (kg ha } \\
\text { 1) }\end{array}$ & 12.86 & 9.00 & 16.45 & 19.82 & 13.50 & 24.54 & 17.19 & 14.53 & 19.10 & 13.67 & 9.54 & 16.15 & 15.89 & 13.53 & 20.00 & 11.22 & 7.30 & 14.23 \\
\hline $\begin{array}{l}\text { Av. K ((kg } \\
\left.\text { ha }^{-1}\right)\end{array}$ & 341.56 & 282.77 & 428.38 & 434.22 & 316.25 & 549.70 & 401.11 & 346.39 & 448.80 & 355.73 & 296.94 & 442.55 & 390.37 & 336.70 & 471.25 & 328.67 & 269.88 & 415.49 \\
\hline $\begin{array}{l}\text { Av. S (kg ha } \\
\text { 1) }\end{array}$ & 11.79 & 7.48 & 15.87 & 16.61 & 21.14 & 12.15 & 14.49 & 10.03 & 19.02 & 19.10 & 15.85 & 21.91 & 14.14 & 8.45 & 18.90 & 10.24 & 5.93 & 14.32 \\
\hline Av. Fe (ppm) & 24.91 & 19.36 & 34.93 & 36.69 & 31.40 & 40.84 & 33.01 & 27.73 & 37.17 & 30.95 & 25.72 & 35.16 & 31.91 & 26.92 & 36.36 & 23.93 & 19.99 & 27.99 \\
\hline $\begin{array}{l}\text { Av. Mn } \\
(\mathbf{p p m})\end{array}$ & 20.00 & 14.36 & 29.93 & 25.56 & 20.28 & 29.72 & 23.31 & 17.11 & 26.55 & 21.01 & 15.73 & 25.17 & 22.50 & 16.77 & 26.30 & 18.51 & 14.50 & 22.50 \\
\hline $\begin{array}{l}\text { Av. Cu } \\
(\mathrm{ppm})\end{array}$ & 0.95 & 0.82 & 1.06 & 1.28 & 1.18 & 1.38 & 1.17 & 1.08 & 1.28 & 0.97 & 0.82 & 1.36 & 1.08 & 0.97 & 1.17 & 0.87 & 0.76 & 0.96 \\
\hline $\begin{array}{l}\text { Av. Zn } \\
\text { (ppm) }\end{array}$ & 0.37 & 0.15 & 0.59 & 0.64 & 0.47 & 0.83 & 0.60 & 0.42 & 0.82 & 0.44 & 0.27 & 0.63 & 0.53 & 0.39 & 0.75 & 0.33 & 0.17 & 0.53 \\
\hline Av. B (ppm) & 0.50 & 0.39 & 0.73 & 0.72 & 0.61 & 0.95 & 0.67 & 0.56 & 0.90 & 0.52 & 0.41 & 0.75 & 0.64 & 0.53 & 0.87 & 0.47 & 0.37 & 0.71 \\
\hline
\end{tabular}




\section{Available Fe}

$\mathrm{Fe}$ is the fourth most abundant element found in soil though it is largely present in forms that cannot be taken up by plants. Soil is typically between 50 to $150 \mathrm{ppm}$ Fe but most of this $\mathrm{Fe}$ is unavailable. Soil factors viz; $\mathrm{pH}$, organic matter content, moisture, aeration and alkali soil condition dominantly affect the $\mathrm{Fe}$ availability. The available $\mathrm{Fe}$ of soils was varied from 19.36 to 34.93 (mean 24.91) ppm, from 31.40 to 40.84 (mean 36.68) ppm, from 27.73 to 37.17 (mean 33.01) ppm, from 25.72 to 35.16 (mean 30.94) ppm, from 26.92 to 36.36 (mean 31.90) and from 19.99 to 27.99 (mean 23.93) for RW, RC, RP, RM, RL and $\mathrm{RF}$, respectively (Table 1 ). The available $\mathrm{Fe}$ of soils under RC cropping system was higher than that of soils under RM, RP, RL, and RF cropping systems. Further, the available Fe of soils under RP cropping system was higher than that of soils under RF cropping systems. In this consequence the available $\mathrm{Fe}$ of soils under RL cropping system was higher than that of soils under RF cropping systems. For other cropping systems the differences in organic carbon were found to be insignificant.

\section{Available Mn}

$\mathrm{Mn}$ is a micronutrient cation. It plays a number of roles and used in photosynthesis, chlorophyll synthesis, and $\mathrm{N}$ absorption. $\mathrm{Mn}$ deficiency is most common on alkaline and poorly drained soils as well as those high in available Fe. The available Mn of soils was varied from 14.36 to 29.93 (mean 19.99) ppm, from 20.28 to 29.72 (mean 25.56) ppm, from 17.11 to 26.55 (mean 23.30) ppm, from 15.73 to 25.17 (mean 21.01) ppm, from 16.77 to 26.30 (mean 22.50) ppm and from 14.50 to 22.50 (mean 18.50) ppm for RW, RC, RP, $\mathrm{RM}, \mathrm{RL}$ and RF, respectively (Table 1 ). The available $\mathrm{Mn}$ of soils under RC cropping system was higher than that of soils under RM, RL, and RF cropping systems. Further, the available Mn of soils under RP cropping system was higher than that of soils under RF cropping systems. In this consequence the available $\mathrm{Mn}$ of soils under RL cropping system was higher than that of soils under RF cropping systems. For other cropping systems the differences in organic carbon were found to be insignificant.

\section{Available $\mathbf{C u}$}

Copper $(\mathrm{Cu})$ is one of eight essential plant micronutrients. The amount of $\mathrm{Cu}$ available to plants varies widely among soils. Ideally, for healthy and productive soil, the concentration of $\mathrm{Cu}$ should be $2-50 \mathrm{ppm}$. $\mathrm{Cu}$ in the soil is held with clay minerals as a cation and in association with organic matter and its deficiency more likely to be seen in plant grown in alkaline soils. The available $\mathrm{Cu}$ of soils was varied from 0.86 to 1.06 (mean 0.95 ) $\mathrm{ppm}$, from 1.18 to 1.38 (mean 1.27) $\mathrm{ppm}$, from 1.08 to 1.28 (mean 1.17) $\mathrm{ppm}$, from 0.82 to 1.36 (mean 0.97) ppm, from 0.97 to 1.17 (mean 1.07) $\mathrm{ppm}$ and from 0.76 to 0.96 (mean 0.87) ppm for RW, RC, RP, RM, $\mathrm{RL}$ and RF, respectively (Table 4.63). Among the cropping systems, the available $\mathrm{Cu}$ was found to be varying significantly (Table 1).

\section{Available Zn}

Zinc is a trace element found in varying concentrations in all soils. Ideally, for healthy and productive soils the concentration of $\mathrm{Zn}$ should be 1-200 ppm. Zn deficiency is most commonly seen on alkaline soil especially if the soil is boggy. Excess levels of $\mathrm{P}$ and $\mathrm{Cu}$ as well as low levels of $\mathrm{N}$ in the oil can also increase the chance of $\mathrm{Zn}$ deficiency. The available $\mathrm{Zn}$ of soils was varied from 0.15 to 0.59 (mean 0.36) ppm, from 0.47 to 0.83 (mean 0.63 ) $\mathrm{ppm}$, from 0.42 to 0.82 (mean 0.59 ) $\mathrm{ppm}$, from 0.27 to 0.63 (mean 0.43 ) $\mathrm{ppm}$, from 0.39 to 0.75 (mean 0.52 ) ppm and from 0.17 to 0.53 (mean 0.32 ) ppm for $\mathrm{RW}$, 
RC, RP, RM, RL and RF, respectively (Table 1). The available $\mathrm{Zn}$ of soils under $\mathrm{RC}$ cropping system was higher than that of soils under RM and RF cropping systems. Further, the available $\mathrm{Zn}$ of soils under RP cropping system was higher than that of soils under RF cropping systems. In this consequence the available $\mathrm{Zn}$ of soils under RL cropping system was higher than that of soils under RF cropping systems. For other cropping systems the differences in organic carbon were found to be insignificant.

\section{Available B}

Boron (B) is one of the essential micronutrient found as anion in soil and required by plant in very small quantity. The available boron is range from 0.03-12 ppm. However, only a small fraction of this amount is available to the crop. B deficiency is highly prevalent in sandy acidic soils with low organic matter, due to the potential for $\mathrm{B}$ leaching. Soils with high adsorption and retention capacity (e.g. soils with high $\mathrm{pH}$ and rich in clay minerals and iron or aluminum oxides) are also commonly impacted by B deficiency. The available B of soils was varied from 0.39 to 0.73 (mean 0.50 ) $\mathrm{ppm}$, from 0.61 to 0.95 (mean 0.72 ) ppm, from 0.56 to 0.90 (mean 0.67 ) ppm, from 0.41 to 0.75 (mean 0.52) ppm, from 0.53 to 0.87 (mean 0.64 ) ppm and from 0.37 to 0.71 (mean 0.47 ) ppm for RW, RC, RP, RM, RL and RF, respectively (Table 1 ). The available $B$ of soils under RC cropping system was higher than that of soils under RM, RL and RF cropping systems. Further, the available B of soils under RP cropping system was higher than that of soils under RF cropping systems.

In conclusion the different rice based cropping systems affects the physical and chemical properties of soils of North hill region of Chhattisgarh. Among the cropping systems, rice-legume cropping systems (RC and RP) sustain better physical and chemical properties of soils in terms of lower BD, higher porosity, soil moisture content, water holding capacity, mean weight diameter, organic carbon, available $\mathrm{N}, \mathrm{P}, \mathrm{K}, \mathrm{S}$, micronutrients, $\mathrm{MBC}, \mathrm{MBN}$, acid and alkali phosphatase activity, and dehydrogenase activity than that of soils under RW, RM, RL and RF cropping systems. Inclusion of legumes in to rice based cropping systems sustain better soil quality than that of soils under RW, RM, RL and RF cropping systems. Therefore, present study recommended that to sustain soil health to become productive for next generation ricelegume cropping systems could be more effective.

\section{References}

Abid, M. and Lal, R. 2008. Tillage and drainage impact on soil quality - I. aggregate stability, carbon and nitrogen pools. Soil and Tillage Research, 100: 89-98.

Alam, M. K., and N. Salahin. 2013. Changes in soil physical properties and crop productivity as influenced by different tillage depths and cropping patterns. Bangladesh Journal of Agricultural Research 38 (2):289-99. doi:10.3329/bjar. v38i2.15891.

Amezketa, E. 1999. Soil aggregate stability-A Review. Journal of Sustainable Agriculture, $\quad 14$ : 83-151. http://dx.doi.org/10.1300/J064v14n0208

Aparicio, V. and Costa, J.L. 2007. Soil quality indicators under continuous cropping systems in the Argentinean Pampas. Soil and Tillage Research, 96(1-2): 155165.

Bama, K. S., and E. Somasundaram. 2017. Soil quality changes under different fertilization and cropping in a Vertisol of Tamil Nadu. International Journal of 
Chemical Studies 5 (4):1961-68.

Berger, K. C., and K. Troug. 1939. Boron determination in soil and plants. Industrial Engineering Chemistry and Analytical Edition II 11:540-45. doi:10.1021/ac50138a007.

Bhattacharyya, T., D. K. Pal, M. Velayutham, P. Chandran, and C. Mandal. 2000. Carbon stock in Indian soils - Issues, priorities and management. International Seminar on Land Resource Management for Food, Employment and Environmental Security (ICLRM), New Delhi, p.1-46.

Bhattacharyya, R., Chandra, S., Singh, R.D., Kundu, S., Srivastva, A.K., Gupta, H.S.2007. Long-term farmyard manure application effects on properties of a silty clay loam soil under irrigated wheat-soybean rotation. Soil Till. Res. 94:386-396

Dumanski, J. and Pieri, C.2000. Land quality indicators: research plan. Agriculture Ecosystem and Environment, 81: 93102.

Filip, Z. 2002. Filip International approach to assessing soil quality by ecologicallyrelated biological parameters. Agriculture, Ecosystems and Environment, 88: 169-174.

Ghosh, P. K., K. K. Bandyopadhyay, R. H. Wanjari, M. C. Manna, A. K. Mishra, M. Mohanty, and A. Subba Rao. 2007. Legume effect for enhancing productivity and nutrient use-efficiency in major cropping systems-An Indian perspec- tive: A review. Journal of Sustainable Agriculture 30 (1):59-86. doi:10.1300/J064v30n01_07.

Ghosh, P.K., Hazra, K.K., Venkatesh, M.S., Nath, C.P., Singh, J., Nadarajan, N.2017. Increasing soil organic carbon through crop diversification in cerealcereal rotations of Indo-Gangetic plain. Proc National Acad Sci India Sec B Biol Sci.89, 429-440. https://doi.org/10.1007/s40011-0170953-X

Hillel, D. 1980. Fundamentals of soil physics, 413. Cambridge, Massachusetts: Academic Press.

Husunjak, S., Filipovic, D. and Kosutic, S. 2002. Influence of different tillage systems on soil properties and crop yield. Rostlinna Vyroba, 48 (6): 249254

Jackson, M. L. 1973. Soil chemical analysis, 52. New Delhi: Prentice Hall of India Pvt. Ltd.

Karlen, D., M. Mausbach, J. Doran, R. Cline, R. Harris, and G. Schuman. 1997. Soil quality: A concept, definition, and framework for evaluation (a guest editorial). Soil Science Society of America Journal 61:4-10. doi:10.2136/ sssaj1997.03615995006100010001x.

Karlen, D.L., Gardner, J.C. and Rosek, M.J. 1998. A soil quality framework for evaluating the impact of CRP. Journal of Production Agriculture, 11: 56-60.

Kumar, N., S. K. Singh, V. N. Mishra, G. P. Obi Reddy, and R. K. Bajpai. 2017. Soil quality ranking of a small sample size using AHP. Journal of Soil and Water Conservation $16 \quad$ (4):339-46. doi:10.5958/2455-7145.2017.00050.9.

Kumar, U., Mishra, V.N. and Kumar, N. 2018a. Comparative study of soil quality indicators for rice-based cropping system in Vertisols of central plain of Chhattisgarh. An Asian Journal of Soil Science, 13 (2) 136-147. DOI: 10.15740/HAS/AJSS/13.2/136-147.

Kumar, U., Mishra, V.N., Kumar, N., Srivastava, L.K. and Bajpai, R.K. 2020. Soil physical and chemical quality under long-term rice-based cropping system in hot humid eastern plateau of India. Communications in Soil Science and Plant Analysis, 51:14, 1930-1945, 
DOI: 10.1080/00103624.2020.1812628.

Kumar, U., V. N. Mishra, N. Kumar, and G. R. Rathiya. 2018b. Methods of soil analysis, 17-22. Ludhiana: Kalyani Publishers.

Kumar, U., V. N. Mishra, N. Kumar, C. K. Dotaniya, and S. Mohbe. 2019b. Effects of long term rice-based cropping systems on soil quality indicators in central plain of Chhattisgarh. International Journal of Current Microbiology and Applied Sciences 8 (4):1544-52. doi:10.20546/ijcmas.2019.804.179.

Kumar, U., V. N. Mishra, N. Kumar, R. K. Jena, L. K. Srivastava, and R. K. Bajpai. 2019a. Characterization and classification of soils under rice-based cropping systems in Balod district of Chhattisgarh. Journal of the Indian Society of Soil Science 67 (2):228-35. doi:10.5958/0974228.2019.00025.2.

Lindsay, W. L., and W. A. Norvell. 1978. Development of a DTPA soil test for zinc, iron, manganese and copper. Soil Science Society of America Journal 42:421-28.

doi:10.2136/sssaj1978.03615995004200 030009x.

Maseko, S. T., and F. D. Dakora. 2013. Rhizosphere acid and alkaline phosphatase activity as a marker of $\mathrm{P}$ nutrition in nodulated Cyclopia and Aspalathus species in the Cape fynbos of South Africa. South African Journal of Botany 89:289-95. doi:10.1016/j.sajb.2013.06.023.

McGarry, D., Bridge, B.J. and Radford, B.J. 2000. Contrasting soil physical properties after zero and traditional tillage of an alluvial soil in the semiarid subtropics. Soil and Tillage Research, 53: 105-115.

Mitsch, W. J., A. Nahlik, P. Wolski, B. Bernal, L. Zhang, and L. Ramberg. 2010. Tropical wetlands: Seasonal hydrologic pulsing, carbon sequestration, and methane emissions. Wetlands Ecology and Management 18:573-86. doi:10.1007/ s11273-0099164-4.

Newton, Z.L., Kennedy, A.N. and Chirwa, R.M. 2011. Grain legume impacts on soil biological processes in sub-Saharan Africa. African Journal of Plant Science, 5(1): 1-7.

Nortcliff, S. 2002. Standardization of soil quality attributes. Agriculture Ecosystem and Environment, 88: 161168.

Olsen, S. R., C. V. Cole, F. S. Watababe, and L. A. Dean. 1954. Estimation of available phosphorus in soils by extraction with sodium bicarbonate. United States Department of Agriculture Circular 939, 19. Washington, DC: US Department of Agriculture.

Orchard, V.A. and Cook, F.J. 1983. Relationship between soil respiration and soil moisture. Soil Biology and Biochemistry, 15: 447-453.

Pagliai, M., Vignozzi, N. and Pellegrini, S. 2004. Soil structure and the effect of management practices. Soil and Tillage Research, 79: 131-143.

Patrick, M., J. S. Tenywa, P. Fbanyat, M. M. Tenywa, D. N. Mubiru, T. A. Basamba, et al., 2013. Soil organic carbon thresholds and $\mathrm{N}$ management in tropical agroecosystems: concepts and prospects. J. Sustain. Dev., 6:31-43.

Rahman, M. N., M. M. Rahman, M. B. Islam, R. A. Begum, and A. T. M. A. I. Mondol, 2007. Effect of tillage practices on soil properties and moisture conservation under Maize -GM-T. Aman cropping sequence. Annual Research Report, Soil Science Division, Bangladesh Agricultural Research Institute, Gazipur.

Richards, L.A. 1954. Diagnosis and 
improvement of saline-alkali soils. USDA Handbook No. 60, U.S. Department of Agriculture, Will Washington, D.C.

Soil Survey Staff, 2014. Keys to Soil Taxonomy. twelfth ed. United States Department of Agriculture, Natural Resources Conservation Service, Washington, DC.

Schjonning, P., Elmholt, S., Munkholm, L.J. and Debosz, K. 2002. Soil quality aspects of humid sandy loams as influenced by organic and conventional long-term management. Agriculture, Ecosystems and Environment, 88(3): 195-214.

Shukla, M.K., Lal, R. and Ebinger, M. 2006. Determining soil quality indicators by factor analysis. Soil and Tillage Research, 87(2): 194-204.

Smith, S.E., Jakobsen, I., Gronlund, M. and Smith, F.A. 2011. Roles of arbuscular mycorrhiz as in plant phosphorus nutrition: interactions between pathways of phosphorus uptake in arbuscular mycorrhizal roots have important implications for understanding and manipulating plant phosphorus acquisition. Plant Physiology, 156: 1050 -1057.

Sparling, G., Schipper, L. 2004. Soil quality monitoring in New Zealand: trends and issues arising from a broad-scale survey. Agriculture, Ecosystems and Environment 104: $545-$ 552. 10.1016/j.agee.2003.11.014

Subbiah, B. V., and G. L. Asija. 1956. A rapid procedure for the determination of available nitrogen in soils. Current Sciences 25:259-60.

Walkley, A., and I. A. Black. 1934. Rapid titration method of organic carbon of soils. Soil Science 37:29-33. doi:10.1097/ 00010694-19340100000003 .

Yoder, R. E. 1936. A direct method of aggregate analysis of soils and a study of the physical nature of erosion losses. Agronomy Journal 28:337-51.

\section{How to cite this article:}

Rajpoot, R. K. Bajpai, L. K. Shrivastava, Uttam Kumar, K. Tedia and Mishra, V. N. 2021. Evaluation of Soil Physical and Chemical Properties under Rice-based Cropping System in Alfisols of Northern Hill Region of Chhattisgarh. Int.J.Curr.Microbiol.App.Sci. 10(01): 27482761. doi: https://doi.org/10.20546/ijcmas.2021.1001.319 